\title{
Misconduct is the main cause of life-sciences retractions
}

\author{
Opaque announcements in journals can hide fraud, study finds.
}

\section{BY ZOË CORBYN}

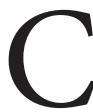
onventional wisdom says that most retractions of papers in scientific journals are triggered by unintentional errors. Not so, according to one of the largestever studies of retractions. A survey ${ }^{1}$ published in Proceedings of the National Academy of Sciences has found that two-thirds of retracted life-sciences papers were stricken from the scientific record because of misconduct such as fraud or suspected fraud - and that journals sometimes soft-pedal the reason.

The survey examined all 2,047 articles in the PubMed database that had been marked as retracted by 3 May this year. But rather than taking journals' retraction notices at face value, as previous analyses have done, the study used secondary sources to pin down the reasons for retraction if the notices were incomplete or vague. These sources included investigations by the US Office of Research Integrity, and evidence reported by the blog Retraction Watch.

The analysis revealed that fraud or suspected fraud was responsible for $43 \%$ of the retractions. Other types of misconduct - duplicate publication and plagiarism - accounted for $14 \%$ and $10 \%$ of retractions, respectively. Only $21 \%$ of the papers were retracted because of error (see 'Bad copy').

Earlier studies had found that the percentage of retractions attributable to error was 1.5-3 times higher ${ }^{2-4}$. "The secondary sources give a very different picture," says Arturo Casadevall, a microbiologist at Yeshiva University in New York, and a co-author of the latest study. "Retraction notices are often not accurate."

Elizabeth Wager, a UK-based medical writer and co-author of a previous study ${ }^{3}$ that relied on journal retraction notices, isn't surprised by the finding of hidden misconduct. "We found many notices that seemed deliberately obscure or vague," she says, speculating that authors and journals may use opaque retraction notices to save face or avoid libel charges.

The latest study shows a ten-fold increase (to about $0.01 \%$ ) in the proportion of papers retracted owing to fraud since 1975 . Previous analyses have seen a growing trend in retractions in general ${ }^{5}$, but the latest report sheds new light on the extent to which fraud is responsible. It also found a correlation between journal impact factor and the number of fraud-induced retractions, says Ferric Fang, a

\begin{tabular}{|c|c|c|}
\hline $\begin{array}{l}\text { TOP TEN RETRACTO } \\
\text { Journals with the mo } \\
\text { fraud or suspected fra }\end{array}$ & $\begin{array}{l}\text { S } \\
\text { retractions } \\
\text { dd, as record }\end{array}$ & $\begin{array}{l}\text { ttributable to } \\
\text { din PubMed. }\end{array}$ \\
\hline Journal & $\begin{array}{l}\text { Number } \\
\text { of articles }\end{array}$ & $\begin{array}{l}2011 \text { impact } \\
\text { factor }\end{array}$ \\
\hline $\begin{array}{l}\text { The Journal of } \\
\text { Biological Chemistry }\end{array}$ & 37 & 5.12 \\
\hline $\begin{array}{l}\text { Anesthesia \& } \\
\text { Analgesia }\end{array}$ & 33 & 3.07 \\
\hline Science & 32 & 32.45 \\
\hline $\begin{array}{l}\text { The Journal of } \\
\text { Immunology }\end{array}$ & 30 & 5.86 \\
\hline $\begin{array}{l}\text { Proceedings of the } \\
\text { National Academy of } \\
\text { Sciences }\end{array}$ & 27 & 10.47 \\
\hline Blood & 21 & 9.79 \\
\hline Nature & 19 & 36.24 \\
\hline $\begin{array}{l}\text { The Journal of } \\
\text { Clinical Investigation }\end{array}$ & 17 & 15.43 \\
\hline Cancer Research & 16 & 8.16 \\
\hline Cell & 13 & 34.77 \\
\hline
\end{tabular}

\section{BAD COPY}

Most retracted papers listed in PubMed were withdrawn owing to fraud or suspected fraud.

$\begin{array}{lrr}\text { Fraud/suspected fraud } & \text { Duplication } & \text { Other } \\ \mathbf{4 3 . 4 \%} & 14.2 \% & \mathbf{1 1 . 3} \%\end{array}$

TOTAL RETRACTED ARTICLES: 2,047

$\begin{array}{ll}\text { Error } & \text { Plagiarism } \\ 21.3 \% & 9.8 \%\end{array}$

microbiologist at the University of Washington in Seattle, who led the study.

Influential journals, including Science, Nature, Proceedings of the National Academy of Sciences and Cell, all appear in the top-ten list of publications with retractions because of fraud or suspected fraud (see 'Top ten retractors'). For some journals, including the two topping the table - The Journal of Biological Chemistry and Anesthesia \& Analgesia - the tally was boosted by multiple retractions from the same few individuals, such as anaesthesiologist Joachim Boldt, formerly of the Ludwigshafen Clinical Center in Germany. Indeed, Fang and his colleagues found that 38 research groups with five or more retractions accounted for $44 \%$ of
Read more in

Nature's retractions

feature:

go.nature.com/cgt4re articles linked to fraud or suspected fraud.

Whether the overall rise in fraud-induced retractions is the result of an increase in misconduct, or simply down to more scrutiny, is an open question, says Fang. It is also unclear whether the high-impact journals have more retractions for fraud because they are checked more closely, or because they are more likely to attract fraudsters. But Fang thinks that the large rewards for publishing in leading journals - which can range from winning grants to receiving tenure - are powerful incentives that could be driving some of the trend. "We need to look at how we have structured the system, so scientists are not given incentives to [commit fraud] quite as strongly," he says.

The survey found some significant geographical differences. Retracted papers with lead authors based in historical scientific superpowers, such as the United States and Germany, were more likely to be linked to fraud. In emerging scientific powers such as India and China, however, plagiarism and duplication caused more of the retractions. "These trends may reflect differences in incentives, cultural norms and proficiency in English among these countries," says Fang.

Ivan Oransky, a New York-based journalist and co-founder of Retraction Watch, suggests setting up a 'transparency index' for journals, to rank them on criteria such as the clarity of their retraction notices. The idea, which he says he would be keen to work on, could provide a much-needed incentive for journals to improve their performance in this area. Data from the current study could also serve as a basis for a retractions database to help scientists avoid wasting time trying to replicate or build on retracted work, he adds.

"I'm not necessarily opposed to the idea, but I have concerns about how such a database could be properly maintained and updated," says Fang. "Our study is merely a snapshot. Creating an accurate, centralized database that could be used as an ongoing resource would be a considerable undertaking." -

1. Fang, F. C., Steen, R. G. \& Casadevall, A. Proc. Natl Acad. Sci. USA http://dx.doi.org/10.1073/ pnas.1212247109 (2012).

2. Steen, R. G. J. Med. Ethics 37, 249-253 (2011).

3. Wager, E. \& Williams, P. J. Med. Ethics 37, 567-570 (2011).

4. Nath, S. B., Marcus, S. C. \& Druss, B. G. Med. J. Aust. 185, 152-154 (2006)

5. Van Noorden, R. Nature 478, 26-28 (2011). 